Tersedia online di: http://ejournal-balitbang.kkp.go.id/index.php/jra

\title{
PERKEMBANGAN EMBRIO DAN LARVA PADA DOMESTIKASI IKAN CUPANG (Betta rubra Perugia, 1893)
}

\author{
Asep Permana\#, Eni Kusrini, Agus Priyadi, dan Sawung Cindelaras \\ Balai Riset Budidaya Ikan Hias \\ Jl. Perikanan No. 13, Pancoran Mas, Depok 16436
}

(Naskah diterima: 17 Oktober 2019; Revisi final: 21 Januari 2020; Disetujui publikasi: 24 Januari 2020)

\begin{abstract}
ABSTRAK
Salah satu jenis ikan cupang alam yang menarik perhatian adalah cupang Betta rubra Perugia, 1893; yang merupakan jenis endemik dari perairan Banda Aceh. Status B. rubra di habitat aslinya sudah mulai sulit diperoleh sedangkan budidayanya belum berkembang. Oleh karena itu, informasi tentang embriogenesis dan perkembangan stadia awal ikan B. rubra sangat diperlukan untuk mendukung keberhasilan pengembangbiakannya. Penelitian ini bertujuan untuk mengetahui embriogenesis dan perkembangan larva ikan B. rubra. Telur dan larva yang digunakan berupa hasil pemijahan alami B. rubra di Balai Riset Budidaya Ikan Hias, Depok. Parameter yang diamati yaitu fase embriogenesis, perkembangan larva, dan benih ikan B. rubra. Pengamatan embriologi di mulai setelah ikan memijah sampai telur menetas, sedangkan perkembangan larva di mulai dari larva menetas sampai menjadi benih atau perkembangan telah sempurna. Pengamatan dilakukan setiap hari di bawah mikroskop binokuler Olympus SZX9 perbesaran 8-25 kali. Hasil penelitian menunjukkan bahwa perkembangan embrio telur B. rubra terjadi selama enam hari atau 144 jam hingga menetas menjadi larva pada suhu $27^{\circ} \mathrm{C}-28^{\circ} \mathrm{C}$. Perkembangan embriogenesisnya yaitu hari pertama setelah memijah di mulai dengan pembelahan awal; hari kedua: blastula; hari ketiga: gastrula; hari keempat: pembentukan bakal kepala dan ekor; hari kelima: pembentukan ovtic vesicle dan notochorda; hari keenam: menetas. Perkembangan larva $\mathrm{H}-3-\mathrm{H}-4$ setelah menetas mata dan mulut mulai membuka; $\mathrm{H}-$ 5- H-6: terbentuk anus dan kuning telur habis; $\mathrm{H}-7$ : peralihan pakan (indogeneous ke exsogeneous) dan metamorfosis terjadi 39 hari atau 936 jam setelah menetas.
\end{abstract}

KATA KUNCl: embryogenesis; perkembangan larva; Betta rubra; Aceh; Indonesia

ABSTRACT: Embriogenesis and larval development of domesticated wild betta (Betta rubra Perugia, 1893). By: Asep Permana, Eni Kusrini, Agus Priyadi, and Sawung Cindelaras

\begin{abstract}
Betta rubra Perugia, 1983 is an endemic ornamental fish found in the swamp areas of Banda Aceh. Due to its appealing physical appearance, B. rubra wild population has been heavily exploited. Current aquaculturetechnology of the species is not yet available which implies an imminent threat to the conservation of this species. Therefore, the domestication the fish species is the first important step toward developing the aquaculturetechnology of the species which requires specific information on embryogenesis and the development of the early stadia $\mathbf{B}$. rubra. This study aimed to determine embryogenesis and larval development of $\mathbf{B}$. rubra. The eggs and larvae used from the natural spawning of B. rubra wild parents reared in the facility of the Ornamental Fish Cultivation Research Center, Depok, Indonesia. The parameters observed were the embryogenesis and early stages development of the fish from larvae to juvenile. Observation of embryogenesis started from eggs fertilization until hatching. The development of larvae was observed from post hatching until fully developed as fish juvenile. Embryonic and larval development were monitored daily using an Olympus $S Z X 9$ binocular microscope with $8 x-25 x$ magnification. The results showed thatthe embryogenesis of B. rubra lasted for six days or 144 hours until it hatched. The development stages of the embryogenesis after fertilization are as follow: division phase on the first day; blastula on the second day; gastrula on the third day; formation of heads and tails on the fourth day; formation of ovtic vesicles and notochordas on the fifth day; hatch on the sixth day. Larval development consists of: eyes and mouth begin to open at three to four days after hatching; anus is formed and the yolk is gone between the fifth and sixth days; intermediate feed (indogeneous to exsogeneous) at seventh day and metamorphosis at 39 days or 936 hours after hatching.
\end{abstract}

\section{KEYWORDS: embryogenesis; larval development; Betta rubra; Aceh; Indonesia}

\footnotetext{
\# Korespondensi: Balai Riset Budidaya Ikan Hias

Jl. Perikanan No. 13, Pancoran Mas, Depok 16436.

Tel. + 62217520482

E-mail: asep_aa37@ yahoo.co.id
} 


\section{PENDAHULUAN}

Jenis cupang alam yang tersebar di dunia sebanyak 69 spesies yang telah teridentifikasi, dan 48 jenis $(70 \%)$ hidup di perairan Indonesia, serta 37 jenis di antaranya endemik di Indonesia (Tan, 2011). Kecenderungan perkembangan budidaya ikan cupang mulai beralih dari budidaya ikan adu menuju ke ikan hias (Monvises et al., 2009). Namun demikian, ikan cupang al am masih belum mendapatkan perhatian yang layak dari para penggemar domestik, padahal penggemar ikan cupang di luar negeri sangat gandrung akan cupang alam bahkan International Betta Contest (IBC) dalam tema konvensinya tahun 2009 mengangkat ikan cupang alam. Pada even tersebut dipamerkan koleksi ikan cupang alam asli Indonesia dalam jumlah yang besar yang mengundang antusiasme masyarakat untuk memilikinya.

Salah satu jenis ikan cupang alam yang menarik perhatian adalah ikan cupang Betta rubra Perugia, 1893 yang merupakan jenis endemik di perairan Banda Aceh. Habitat ikan ini rawa-rawa berair keruh di hutan lebat di dataran rendah dengan air coklat kehitaman. Umumnya berada di habitat yang terhalang dari sinar matahari, karena tertutup oleh daun-daun pohon dan tumbuhan yang tebal, serta air dengan suhu antara $22^{\circ} \mathrm{C}-27^{\circ} \mathrm{C}$ dan $\mathrm{pH} 5,0-6,5$. Serangga kecil dan zooplankton di alam merupakan makanannya. Secara ekssitu atau di luar habitatnya akan mudah menerima makanan kering, namun harus disertai makanan hidup, seperti cacing sutra dan jentik nyamuk.

Warna B. rubra khas coklat kehitaman. Panjang maksimalnya mencapai tujuh sentimeter. Saat panjang badannya mencapai $2-2,5 \mathrm{~cm}$; B. rubra mulai mencari pasangan yang diikuti dengan perubahan corak warna menjadi cerah pada jantan dan betina. Ikan jantan akan menjadi berwarna cerah, dan memiliki sirip-sirip yang dapat dikembangkan dengan indah, untuk menarik perhatian betina. Sedangkan betina memiliki warna tubuh agak buram, dan warna tidak terlalu terlihat. Jenis ikan cupang ini termasuk menyimpan telur dalam mulut induk jantan (mouth breeder). Menurut data dari IBC yang diselenggarakan tahun 2017, B. rubra sangat diminati dan diburu oleh para penggemar ikan cupang alam, berkualitas ekspor, dan memiliki harga cukup tinggi Rp450.000,00.

Keberadaan ikan B. rubra di daerah asal sudah sulit ditemukan. Sementara itu, budidaya ikan ini belum dikuasai oleh para pembudidaya. Salah satu fase penting/kritis dalam pengembangbiakan adalah data perkembangan awal pada stadia embrio (embriogenesis) dan larva sampai organ-organ terbentuk sempurna. Penelitian ini dilakukan untuk mengetahui perkembangan stadia awal ikan cupang dari embrio, larva hingga ukuran benih.

\section{BAHAN DAN METODE}

\section{Pemeliharaan Induk}

Penelitian ini dilaksanakan di Balai Riset Budidaya Ikan Hias, Depok. Induk yang dipakai dalam pemijahan adalah induk G0 tangkapan alam dari daerah Aceh. Induk dipelihara dalam styrofoam ukuran $40 \mathrm{~cm} \times 40$ $\mathrm{cm} \times 60 \mathrm{~cm}$ untuk betina secara massal dan jantan secara soliter dalam akuarium. Sistem pemeliharaan induk secara stagnan, pergantian air total dilakukan dua minggu sekali dengan air yang sudah diendapkan minimal 24 jam. Selama pemeliharaan induk diberi pakan bloodworm (larva Chironomus sp.) dan jentik nyamuk (larva Culex sp.) secara ad satiation. Suhu pemeliharaan induk berada pada kisaran $27^{\circ} \mathrm{C}-30^{\circ} \mathrm{C}$.

\section{Pemijahan}

Pemijahan menggunakan wadah berupa toples plastik bulat diameter $10 \mathrm{~cm}$ yang masing-masing dilengkapi shelter. Rasio kelamin induk yang digunakan adalah satu jantan : satu betina. Setelah memijah, induk jantan akan mengerami telur sampai menetas di dalam mulutnya. Setelah ikan memijah, kemudian dilakukan pengamatan terhadap perkembangan embrio telur dan perkembangan larva hingga benih dengan cara mengambil sampel untuk pengamatan setiap hari.

\section{Pengamatan Perkembangan Embrio}

Data perkembangan embrio telur didapat dengan cara memuntahkan telur dari mulut induk jantan. Proses pemuntahan telur yaitu dengan cara membuka mulut induk jantan yang sedang mengerami telur sampai telurnya keluar, proses ini dilakukan di dalam air. Pemuntahan telur dilakukan secara berulang, mulai dari sehari setelah memijah, dua hari setelah memijah dan seterusnya sampai didapat data embriologi yang lengkap sampai menetas. Proses ini sekaligus untuk mengetahui seberapa lama waktu pengeraman telur di mulut induk jantan dari mulai memijah sampai menetas.

Untuk pengamatan, telur diambil sebanyak 20 butir dan diletakkan dalam wadah inkubasi dengan suhu $27^{\circ} \mathrm{C}-28^{\circ} \mathrm{C}$. Pengambilan telur dengan cara memuntahkan telur dari mulut induk sebelum larva menetas. Telur kemudian diamati di bawah mikroskop binokuler Olympus SZX9 yang terhubung dengan kamera dan komputer dengan perbesaran 8-25 kali untuk melihat tahapan embriogenesis. Pengamatan perkembangan embrio dilakukan setiap hari. 


\section{Pengamatan Perkembangan Larva}

Perkembangan larva diamati hingga umur 39 hari atau benih yang telah mengalami metamorfosis mirip seperti induknya. Sampel larva diambil dengan menggunakan pipet plastik $3 \mathrm{~mL}$ untuk menghindari stres dan kerusakan pada organ tubuh larva, selanjutnya sampel ditempatkan di atas gelas objek. Pengamatan dilakukan dengan alat dan metode yang sama untuk pengamatan perkembangan telur. Parameter yang diamati adalah panjang total, perkembangan organ, dan bukaan mulut. Jumlah sampel pada setiap pengamatan sebanyak tiga ekor larva.

\section{Analisis Data}

Data yang diperoleh dari setiap tahap perkembangan embrio dan larva hingga benih dianalisis secara deskriptif tiap fase perkembangan yang mengacu pada Iwamatsu (2004).

\section{HASIL DAN BAHASAN}

\section{Perkembangan Embrio}

Setelah dilakukan pengamatan perkembangan embrio, didapat data embriologi seperti terlihat pada Tabel 1.

Berdasarkan data pada Tabel 1 dapat dilihat bahwa lama waktu pengeraman telur di dalam mulut induk jantan dari mulai memijah sampai menetas adalah enam hari. Waktu penetasannya cukup lama, berbeda dengan $B$. imbellis yang memerlukan waktu sekitar 29 jam 04 menit (Cindelaras et al., 2015), 35 jam (Narwati, 2012), dan pada B. splendens sekitar 38 jam (Duarte et al., 2012; Valentin et al., 2013; Annur et al., 2016).

Setelah menetas, larva masih akan dierami di mulut induk jantan sampai kuning telur habis dan sudah bisa berenang. Waktu yang diperlukan larva dari menetas sampai kuning telur habis dan bisa berenang memerlukan waktu sekitar 6-7 hari. Jadi pada B. rubra kisaran total waktu pengeraman di mulut induk dari mulai telur sampai larva siap dikeluarkan adalah 12-13 hari. Berbeda dengan larva B. imbellis yang dilaporkan Cindelaras et al. (2015) dapat berenang bebas setelah 2-3 hari dari penetasan, dan Groth (1970) juga melaporkan hal yang sama pada B. splendens.

Pada waktu pengeluaran telur dari mulut, telur yang didapat selain diamati juga dicoba untuk ditetaskan. Namun ternyata telur-telur yang masih muda atau baru beberapa hari dari memijah tidak berhasil menetas. Waktu pengeluaran telur dari mulut yang aman agar telur juga menetas adalah empat hari setelah memijah atau dua hari sebelum menetas. Pengeluaran telur dari mulut pada umur ini tidak memengaruhi penetasan telur atau telur masih bisa menetas dengan derajat tetas yang tinggi. Cara ini bisa dilakukan untuk efisiensi waktu pengeraman supaya tidak terlalu lama dan agar induk cepat memijah lagi.

Pada hari pertama setelah memijah, telur berbentuk bulat berukuran $\pm 2 \mathrm{~mm}$, terlihat chorion yang bening dengan kuning telur yang berwarna kekuningan agak keruh dan tidak tembus cahaya. Diameter telur ini cukup besar dibandingkan telur B. splendens yaitu sekitar $\pm 1,08 \mathrm{~mm}$ (Valentin et al., 2003). Nilai ini cukup jauh dengan diameter rata-rata untuk spesies ikan hias yaitu 0,8 mm (Watson \& Chapman, 2002). Tahap perkembangan embrio masih fase awal dan belum terlihat adanya blastomer yang muncul. Pada hari pertama setelah menetas perkembangan embrio terjadi dari mulai pembelahan dua sel sampai 64 sel. Waktu perkembangan sampai fase ini yang memerlukan waktu sehari, tergolong lama. Pada B. imbellis waktu yang diperlukan sampai fase ini hanya memerlukan waktu 55 menit dari pembuahan (Cindelaras et al., 2015).

Hari kedua setelah memijah terjadi pembelahan 64 sel lebih, ditandai dengan munculnya blastomer, kemudian terus membelah melewati 128 sel, dan fase blastula di mana pembelahan semakin tidak jelas dan saling bertumpuk. Pada B. imbellis, pengamatan pada fase 128 sel terjadi pada 1 jam 16 menit setelah pembuahan pada suhu $27^{\circ} \mathrm{C}-28^{\circ} \mathrm{C}$ (Cindelaras et al., 2015), sedangkan pada B. splendens fase pembelahan 128 sel terjadi pada dua jam setelah pembuahan (Groth, 1970).

Hari ketiga setelah memijah, fase blastula berakhir dan dilanjutkan dengan fase gastrula di mana blastomer menunjukkan gerakan invaginasi dan membentuk rongga yang dinamakan gastrocoel. Blastomer kemudian menutupi 50\%(50\%epiboly) dari kuning telur yang menunjukkan berlangsungnya perisai embrio, fase gastrula akhir nampak epiboly telah menutupi $80 \%$ 90\%dari kuning telur (Kimmel et al., 1995).

Hari keempat setelah memijah, mulai fase pembentukan organ ditandai dengan munculnya bakal kepala (head bud) pada kutub anima dan bakal ekor (tail bud) di kutub vegetal, serta epiboly telah tertutup sebanyak 100\% (Kimmel et al., 1995). Pada ikan B. imbellis, pengamatan pada fase ini terjadi pada 8 jam 6 menit setelah pembuahan (Cindelaras et al., 2015).

Hari kelima setelah memijah, fase pembentukan organ lanjutan: optic vesicle atau rongga mata sudah terbentuk yang diikuti dengan pembentukan notochord atau sumbu tulang belakang. Otic vesicle sudah terlihat pada fase embrio ini dan berada di belakang kepala yang berbentuk seperti gelembung dengan dua buah titik. Pada ikan B. imbellis, pengamatan pada fase ini 
Tabel 1. Pekembangan embrio ikan Betta rubra dibandingkan dengan B. imbelis Table 1. Embryo development of Betta rubra compared to B. imbelis

\begin{tabular}{|c|c|c|}
\hline $\begin{array}{l}\text { Waktu } \\
\text { Time }\end{array}$ & $\begin{array}{l}\text { Pekembangan embrio } \mathrm{B} \text {. rubra } \\
\text { pada suhu } 27^{\circ} \mathrm{C}-28^{\circ} \mathrm{C} \\
\text { Development embrio of } \mathrm{B} \text {. rubra } \\
\text { at } 27^{\circ} \mathrm{C}-28^{\circ} \mathrm{C} \text { temperature }\end{array}$ & $\begin{array}{l}\text { Pekembangan embrio } \mathrm{B} \text {. imbellis } \\
\text { pada suhu } 27^{\circ} \mathrm{C}-28^{\circ} \mathrm{C} \\
\text { Development embrio of } \mathrm{B} \text {. imbellis } \\
\text { at } 27^{\circ} \mathrm{C}-28^{\circ} \mathrm{C} \text { tem per ature } \\
\text { (Cindelaras et al ., 2015) }\end{array}$ \\
\hline \multirow[t]{2}{*}{$\begin{array}{l}\text { Sehari } \\
\text { setelah memijah } \\
\text { (24 jam) } \\
\text { One day } \\
\text { post hatching } \\
\text { (24 hours) }\end{array}$} & ys & $y$ \\
\hline & $\begin{array}{l}\text { Telur terbuahi: pembelahan sel lambat, fase } \\
\text { awal pembelahan, telur bulat berukuran } \pm 2 \\
\text { mm, chorion bening, kuning telur berwarna } \\
\text { kekuningan agak keruh, dan tidak tembus } \\
\text { cahaya; ch: chorion, ys: yolksac }\end{array}$ & $\begin{array}{l}\text { (Larva memenunı chorıon) } \\
\text { Pembelahan sel cepat, dalam waktu } \\
20 \text { jam } \\
\text { larva sudah memenuhi chorion dan } \\
\text { segera menetas }\end{array}$ \\
\hline \multirow[t]{2}{*}{$\begin{array}{l}\text { Dua hari } \\
\text { setelah memijar } \\
\text { (48 jam) } \\
\text { Two days } \\
\text { post hatching } \\
\text { (48 hours) }\end{array}$} & & $\int_{m}^{\text {ba }}$ \\
\hline & $\begin{array}{c}\text { Memasuki fase blastula: pembelahan banyak } \\
\text { sel dengan terlihat adanya blastomer; } \\
\text { blm: blastomer }\end{array}$ & $\begin{array}{l}\text { (Larva menetas) } \\
\text { Larva menetas dalam waktu } 29 \text { jam } \\
04 \text { menit }\end{array}$ \\
\hline \multirow[t]{2}{*}{$\begin{array}{l}\text { Tiga hari } \\
\text { setelah memijah } \\
\text { (72 jam) } \\
\text { Three days } \\
\text { post hatching } \\
\text { (72 hours) }\end{array}$} & & \\
\hline & $\begin{array}{c}\text { Fase gastrula: blastomer menunjukkan } \\
\text { gerakan invaginasi dan membentuk rongga } \\
\text { yang dinamakan gastrocoel, blastomer } \\
\text { kemudian menutupi } 50 \%(50 \% \text { epiboly) dari } \\
\text { kuning telur yang menunjukkan } \\
\text { berlangsungnya perisai embrio (embryo } \\
\text { shield) pada fase perisai embrio, pada } \\
\text { gastrula akhir nampak apabila epiboly telah } \\
\text { menutupi } 80 \% 90 \% \text { dari kuning telur; } \\
\text { sh: shield }\end{array}$ & \\
\hline
\end{tabular}


Tabel 1. Pekembangan embrio ikan Betta rubra dibandingkan dengan B. imbelis

Table 1. Embryo development of Betta rubra compared to $\mathbf{B}$. imbelis

\begin{tabular}{|c|c|}
\hline $\begin{array}{l}\text { Empat hari } \\
\text { setelah memijah } \\
\text { (96 jam) } \\
\text { Four days } \\
\text { post hatching } \\
\text { (96 hours) }\end{array}$ & $\begin{array}{l}\text { Fase pember } \\
\text { bud) pada kutub anima dan bakal ekor (tail } \\
\text { bud) di kutub vegetal, serta epiboly telah } \\
\text { tertutup sebanyak } 100 \% \text { hb: head bud, tb: } \\
\text { tail bud }\end{array}$ \\
\hline $\begin{array}{l}\text { Lima hari } \\
\text { setelah memijah } \\
\text { (120 jam) } \\
\text { Five days } \\
\text { post hatching } \\
\text { (120 hours) }\end{array}$ & $\begin{array}{l}\text { Fase peml opv } \\
\text { vesicle atau rongga mata sudah terbentuk } \\
\text { yang diikuti dengan pembentukan notochord } \\
\text { atau sumbu tulang belakang. Otic vesicle } \\
\text { sudah terlihat pada fase embrio ini dan } \\
\text { berada di belakang kepala yang berbentuk } \\
\text { seperti gelembung dengan dua buah titik; } \\
\text { sm: somite, opv: optic vesicle, ov: otic vesicle }\end{array}$ \\
\hline $\begin{array}{l}\text { Enam hari } \\
\text { setelah memijah } \\
\text { (144 jam) } \\
\text { Six days } \\
\text { post hatching } \\
\text { (144 hours) }\end{array}$ & $\begin{array}{l}\text { Larva cu } \\
\text { jantung, ys: yolksac, ba: bakal anus, s: somite, } \\
\text { bse: bakal sirip ekor }\end{array}$ \\
\hline
\end{tabular}

terjadi pada jam ke-14sampai jam ke-20 setelah pembuahan (Cindelaras et al., 2015).

Hari keenam setelah memijah, larva cupang sudah menetas dan larva sudah memiliki bakal mata, jantung, yolksac, bakal anus, somite, dan bakal sirip ekor. Menurut Braum (1978), penetasan terjadi akibat pergerakan embrio yang kuat pada saat bersamaan dengan semakin melunaknya lapisan khorion. Selain pergerakan aktivitas enzim juga berperan dalam pelunakan chorion sehingga mudah untuk dipecahkan oleh embrio (Blaxter, 1969). Pada ikan B. imbellis, larva cupang menetas setelah mengalami perkembangan selama 29 jam 04 menit (Cindelaras et al., 2015), hal yang sama seperti pada B. splendens menetas selama 29 jam (Valentin et al., 2013).

\section{Perkembangan Larva}

Periode perkembangan larva berlangsung sampai umur 39 hari. Periode ini berlangsung lebih lama dibandingkan dengan periode perkembangan larva B. imbellis yang berlangsung sampai umur 23 hari pada suhu ruang (Rahmawati \& Kusrini, 2013) dan 32 hari pada B. splendens (Valentin et al., 2013).

Panjang total (TL) larva setelah menetas sekitar 3,454 mm; sedangkan pada B. imbellis memiliki panjang 
total sekitar $4 \mathrm{~mm}$ (Rahmawati \& Kusrini, 2013) ukurannya lebih besar dibandingkan B. splendens sekitar 2,47 mm. Perkembangan organ larva B. rubra dibagi menjadi beberapa stadia, setiap stadia memiliki karakter perkembangan larva yang utama dan spesifik.

Sehari setelah menetas, larva mempunyai kuning telur yang cukup besar dengan diameter $1,07 \mathrm{~mm}$; sudah ada pigmentasi, bintik mata sudah terlihat namun belum berfungsi, mulut belum membuka, organ pencernaan belum terbentuk, dan sirip belum terbentuk (Gambar 1a); dan pada hari kedua setelah menetas, sirip ekor larva mulai berkembang dan pigmentasi sudah lebih jelas (Gambar 1b). Larva berwarna transparan agak kekuningan terutama pada kuning telur, pembuluh darah terlihat jelas terutama di bagian depan kuning telur. Larva mengandalkan kuning telur sebagai sumber energi (endogeneus energy), larva bersifat demersal karena belum memiliki gelembung renang, bentuk badan agak pipih dengan kuning telur bulat sempurna.

- Stadia-1 (hari pertama dan kedua setelah menetas)
Perkembangan utama stadia kedua adalah mulai membukanya mata (Gambar 2a) dan juga mulut (Gambar 2b) namun masih belum berfungsi, selain itu pigmentasi juga sudah banyak dan jelas. Volume kuning telur pada stadia ini mulai berkurang menjadi 0,301$0,133 \mathrm{~m}^{3}$. Panjang total larva berkisar 4,181 mm. Organ pencernaan belum terbentuk, sirip ekor semakin berkembang, dan sirip anal mulai terbentuk.

Fase membukanya bukaan mulut akan berjalan beriringan dengan penyerapan kuning telur, serta penyempurnaan organ pencernaan dan merupakan fase yang penting. Fase membukanya mulut pada larva ikan berbeda-beda, pada larva ikan B. imbellis mulut membuka pada jam ke-36 setelah menetas (Cindelaras et al., 2015).

Terbentuknya gelembung renang dan sirip dada (Gambar 3a) merupakan bagian penting dari fase ini. Volume kuning telur mengecil atau terserap hingga tinggal $1 \%$ pada hari kelima dan terserap habis pada
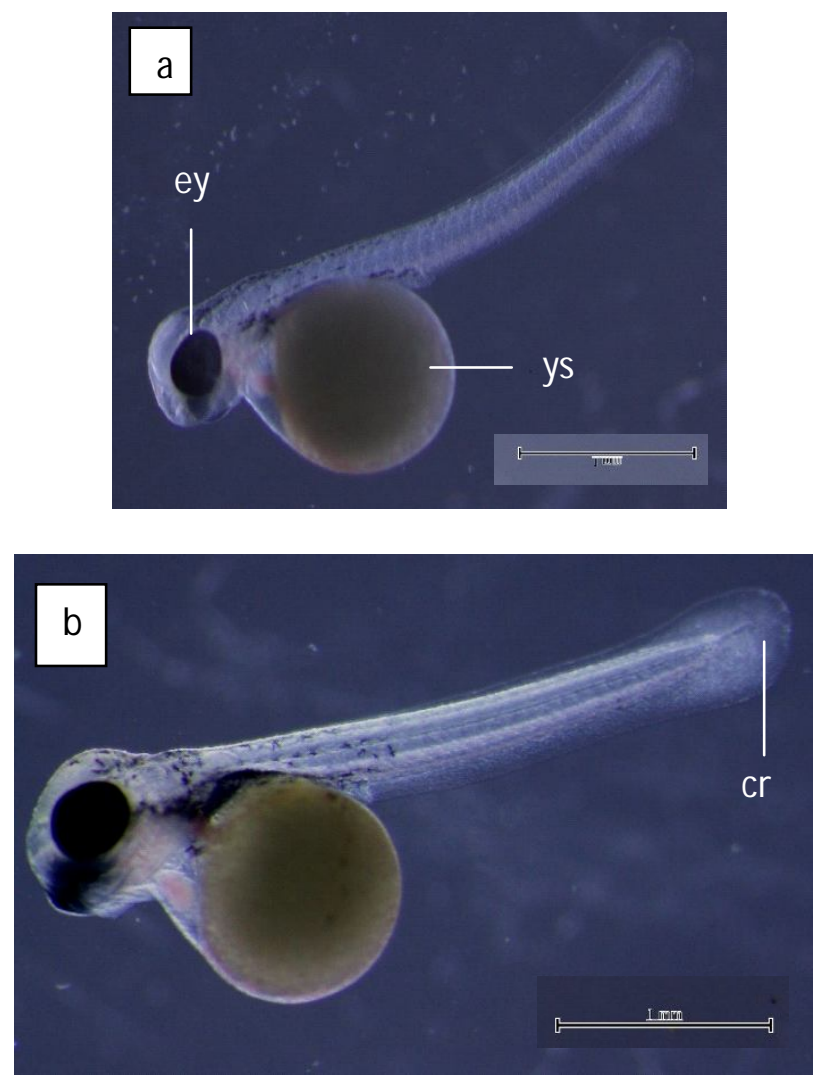

Gambar 1. Perkembangan larva B. rubra pada hari pertama menetas (a) dan hari kedua setelah menetas (b), mulai muncul pigmentasi; ey: eye (mata), ys: yolk sac (kuning telur), cr: caudal rays (sirip ekor).

Figure 1. Larval development of B. rubra on the first day after hatching (a) and the second day after hatching (b), pigmentation begins; ey: eye, ys: yolk sac, cr: caudal rays. 
- Stadia-2 (hari ke-3 hingga ke-4 setelah menetas): fase mata dan bukaan mulut mulai membuka
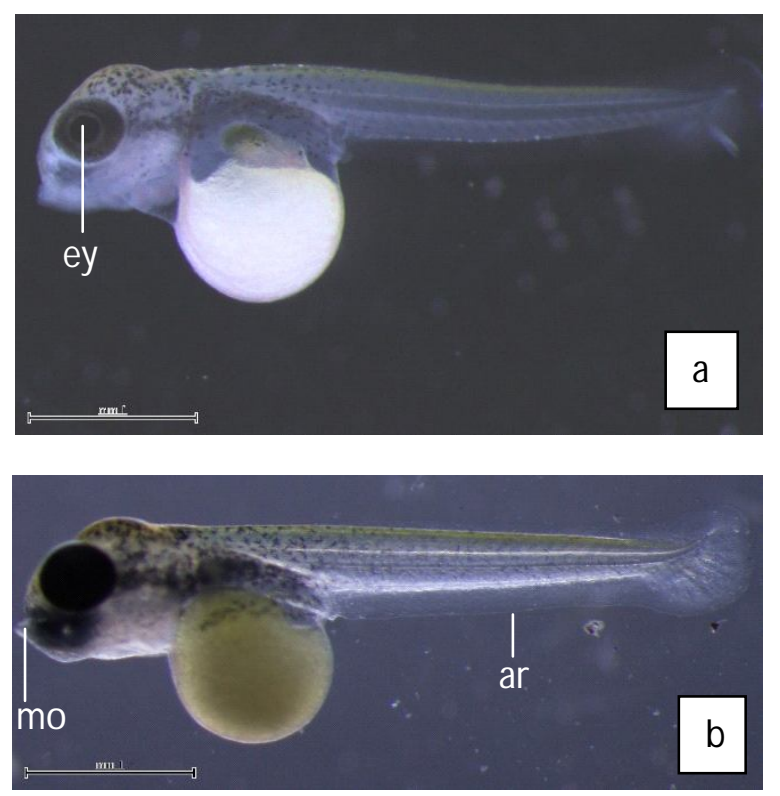

Gambar 2. Perkembangan larva B. rubra pada hari ketiga setelah menetas (a) dan hari keempat setelah menetas (b); ey: eye (mata), mo: mouth (mulut), ar: anal rays (sirip anal).

Figure 2. Larval development of $\mathbf{B}$. rubra on the third day after hatching (a) and fourth day after hatching (b); ey: eye, mo: mouth, ar: anal rays.

- Stadia-3 (hari ke-5 hingga ke-6 setelah menetas): fase gelembung renang, sirip dada, dan terbentuknya anus
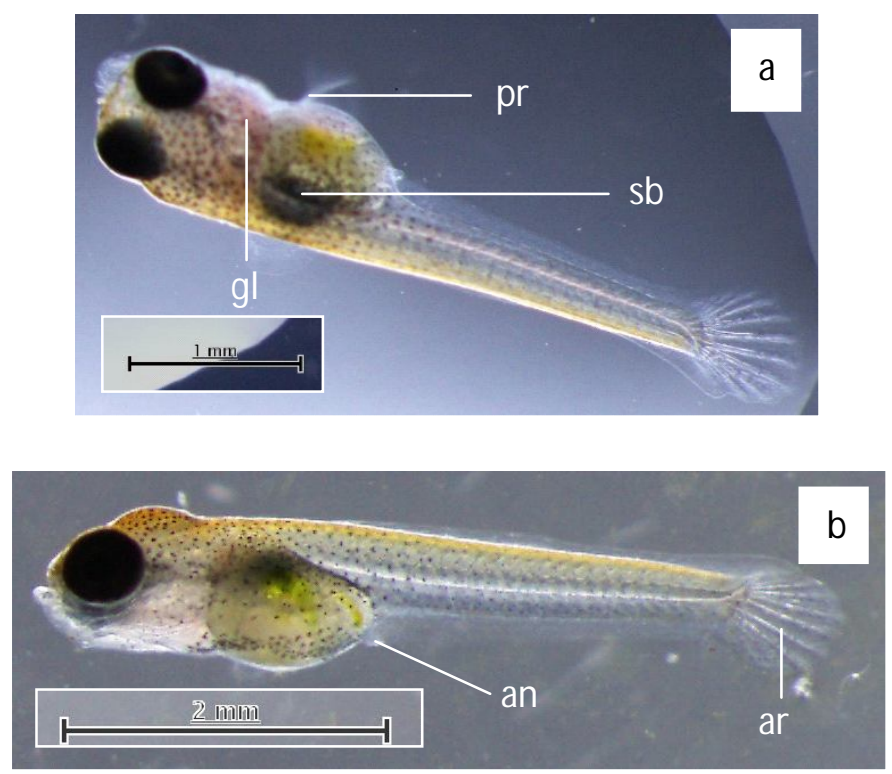

Gambar 3. Perkembangan larva B. rubra pada hari kelima setelah menetas (a) dan hari keenam setelah menetas (b); sb: swim bladder (gelembung renang), pr: pectoral rays (sirip dada), gl: gill (insang), an: anus, ar: anal rays (sirip ekor).

Figure 3. Larval development of $\mathbf{B}$. rubra on the fifth day after hatching (a) and sixth day after hatching (b); sb: swim bladder, pr: pectoral rays, gl: gill, an: anus, ar: anal rays. 
hari keenam. Pada kondisi ini bukaan mulut ikan sudah terbuka dan bakal saluran pencernaan hingga anus juga sudah mulai terbetuk. Lamela insang dan tulang sirip ekor juga mulai terlihat lebih jelas (Gambar 3b). Panjang total larva berkisar 5,215 mm.

Pada hari ketujuh, larva sudah bisa diberi pakan dari luar berupa nauplii Artemia yang baru menetas karena bukaan mulut larva, sistem pencernaan hingga anus terlihat lebih sempurna. Sesuai dengan pernyataan Yúfera \& Darias (2007), bahwa ketika larva mulai diberi pakan dari luar, penting untuk diperhatikan bahwa semua struktur terkait dengan pencernaan, sudah siap. Bukaan mulut awal larva B. rubra adalah $385,2 \mu$ m atau $0,385 \mathrm{~mm}$ dengan bukaan mulut sebesar ini bisa memakan nauplii Artemia di mana ukurannya yaitu 0,30 mm (Rahmawati \& Kusrini, 2013).
Pada fase ini sirip dada (pectoral rays) sudah terbentuk lebih sempurna (Gambar 4a) dan jika diamati alat pencernaan (lambung dan usus) mulai terisi pakan alami. Sirip anal juga sudah mulai memanjang (Gambar $4 b)$, serta sirip punggung (dorsal rays) sudah mulai berkembang (Gambar 4c). Pada fase ini panjang total ikan berkisar antara 5,471-8,337 mm.

Perkembangan organ sirip merupakan bagian yang sangat penting dalam proses perkembangan larva untuk beberapa spesies ikan. Pada ikan B. rubra perkembangan sirip dimulai dari sirip dada, ekor, perut, anal, dan terakhir punggung.

Pada stadia ini tidak terjadi perubahan morfologi dan perkembangan organ tubuh ikan yang signifikan. Perkembangan larva lebih mengarah pada

- Stadia-4 (hari ke-7 hingga ke-17 setelah menetas); fase peralihan pakan dari endogenous feeding ke exogenous feeding dan pembentukan dan perkembangan sirip
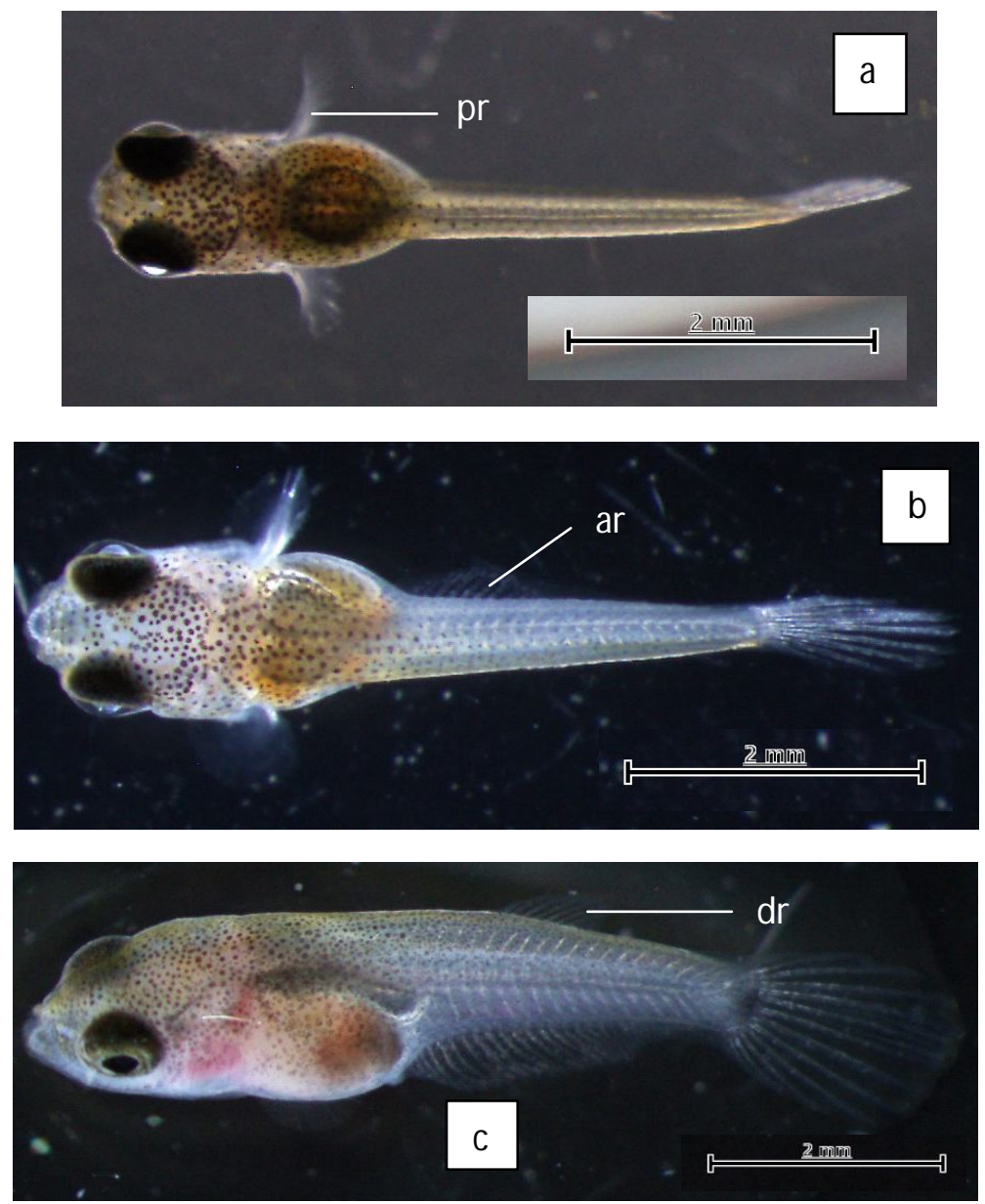

Gambar 4. Perkembangan larva B. rubra pada hari ketujuh setelah menetas (a), hari ke-11 setelah menetas (b), dan ke-17 setelah menetas (c); pr: pectoral rays (sirip dada), ar: anal rays (sirip anal), dr: dorsal rays (sirip punggung).

Figure 4. Larval development of $\mathbf{B}$. rubra on the seven day after hatching (a), eleventh day after hatching (b), and seventeenth day after hatching (c); pr: pectoral rays, ar: anal rays, dr: dorsal rays. 
penyempurnaan proses-proses pembentukan organ di antaranya; perkembangan sirip anal, ekor, dan dorsal semakin panjang. Panjang total larva meningkat menjadi 9,116-14,34 mm; pigmen atau bar hitam di bagian kepala dan badan mulai nampak jelas (Gambar 5c).
Perkembangan larva B. rubra mencapai fase akhir pada hari ke-29 sampai ke-31 setelah menetas. Panjang larva pada stadia ini yaitu 14,79-20,73 mm. Semua sirip telah memiliki jari-jari kelas dan tidak menyatu dengan membran sirip (Gambar 6a) dan semua pigmen di bagian kepala dan badan sudah sama seperti kondisi

- Stadia-5 (hari ke-18 hingga ke-28 setelah menetas); penyempurnaan organ
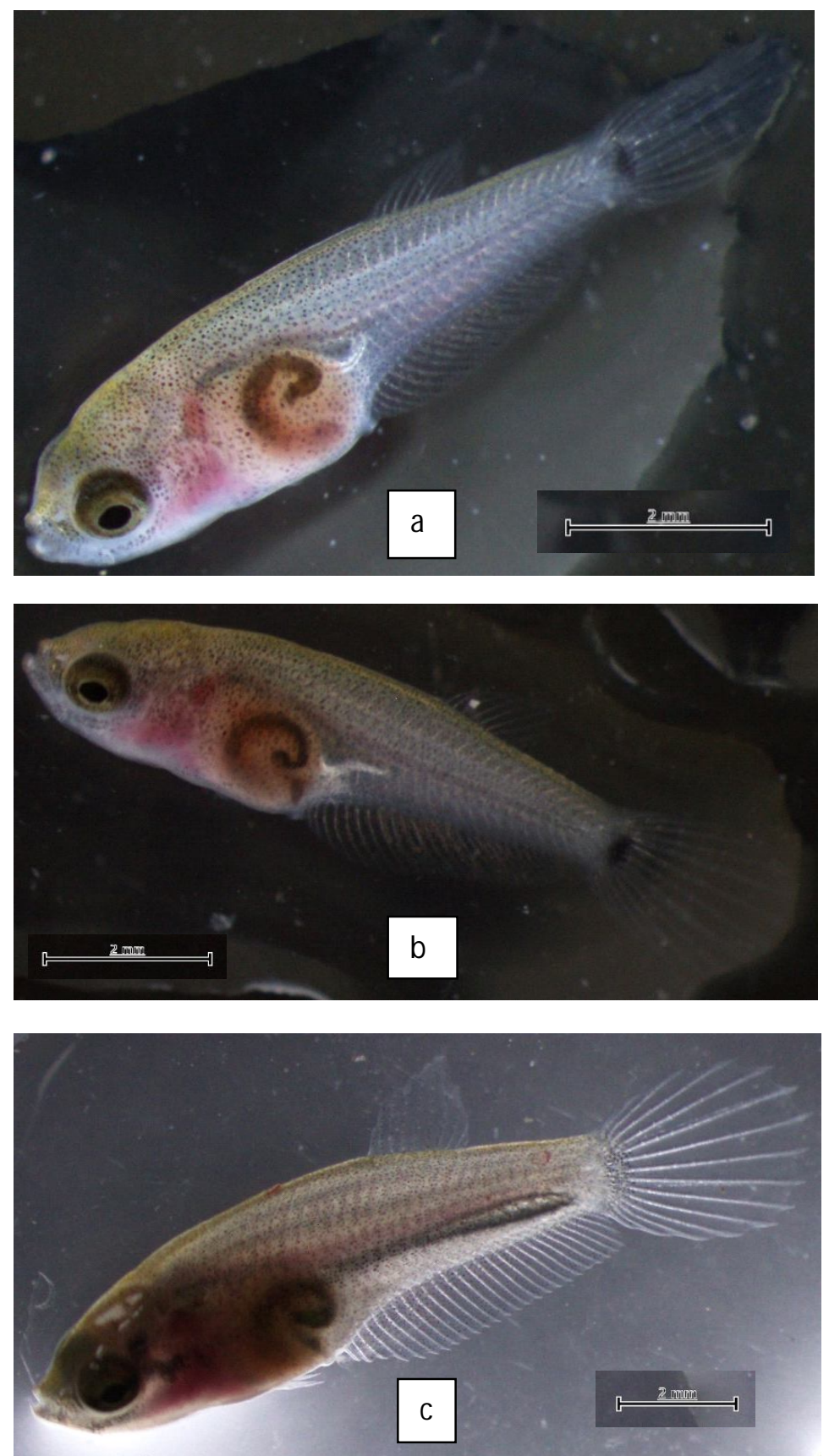

Gambar 5. Perkembangan larva B. rubra pada hari ke-18 setelah menetas (a), hari ke-20 setelah menetas (b), dan ke-28 setelah menetas (c); nampak perkembangan sirip semakin mendekati sempurna.

Figure 5. Larval development of B. rubra on the eighteenth day after hatching (a) twentieth day after hatching (b), and twenty-eighth day after hatching (c); the fins almost fully developed. 
- Stadia-6 (hari ke-29 hingga ke-39 setelah menetas); fase akhir perkembangan larva
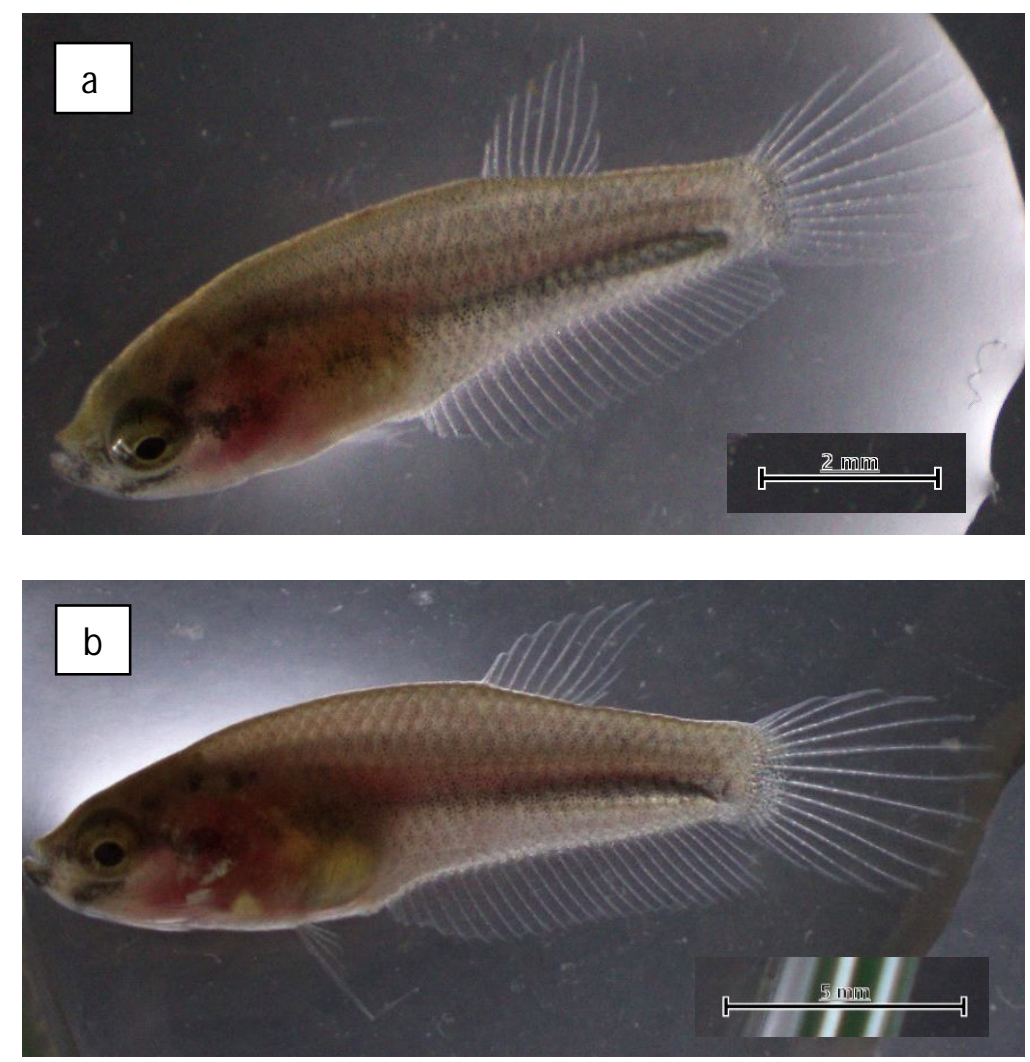

Gambar 6. Perkembangan larva B. rubra pada hari ke-29 setelah menetas (a), dan hari ke-39 setelah menetas di mana larva sudah definitif atau sama dengan induknya (b).

Figure 6. Larval development of $\mathbf{B}$. rubra on the twenty-ninth day after hatching (a), and thirtyninth day after hatching. Larva fully developed resembling the parent (b).

dewasa (Gambar 6b). Hal ini dibuktikan dengan dokumentasi ikan dewasa atau calon induk (Gambar 9b) memiliki bentuk yang sama dengan larva umur 39 hari.

\section{KESIMPULAN}

Perkembangan embrio telur B. rubra berlangsung selama enam hari atau 144 jam sampai menetas menjadi larva pada suhu $27^{\circ} \mathrm{C}-28^{\circ} \mathrm{C}$. Perkembangan larva hingga mencapai ukuran ikan muda yang sempurna membutuhkan waktu 39 hari atau 936 jam dengan fase peralihan pakan terjadi pada H-7 atau 168 jam setelah menetas.

\section{UCAPAN TERIMA KASIH}

Penelitian ini dibiayai oleh APBN 2018 riset perikanan budidaya ikan hias Balai Riset Budidaya Ikan Hias. Terima kasih disampaikan kepada Bapak Hasan, Saudara Asep Solihin, serta Bapak Utay atas bantuannya di lapangan sehingga penelitian ini dapat berlangsung dengan baik.

\section{DAFTAR ACUAN}

Annur, Madinawati, Mangitung, S.F., \& Rusaini. (2016). Embriogenesis ikan cupang (Betta splendens). J. Agrisains, 17(3), 137-140.

Blaxter, J.H.S. (1969). Development of egg and larvae. In Hoar, W.S. \& Randall. (Eds.). New York, London: Academic Press. Fish Phisiology, XI, 178-253.

Braum, E. (1978). Ecological aspect of the survival of fish egg, embryos and larvae. In Gerking, S.D. (Eds.). Ecology of Freshwater Fish Production. Oxford: Blackwell Scientific Publication, p. 102-131.

Cindelaras, M., Prasetio, A.B., \& Kusrini, E. (2015). Perkembangan embrio dan awal larva ikan cupang alam (Betta imbellis ladiges 1975). Widyariset, 1(1), 1-10.

Duarte, S.C., Vasconcellos, B.F., Vidal, Júnior, M.V., Ferreira, A.V., Mattos, D.C., \& Branco, A.T. (2012). Ontogeny and embryonic description of Betta splendens, Perciformes (Regan, 1910). Rev. Bras. Saúde Prod. Anim., Salvador, 13(3), 880-893. 
Groth, W.O. (1970). Embryology of siamese fighting fish, Betta splendens. Thesis. The School of Graduate studies. lowa: Drake University.

Iwamatsu, T. (2004). Review: Stages of normal development in the medaka Oryzias latipes. Mechanisms of Development, 121, 605-618.

Kimmel, C.B., William, W.B., Seth, R.K., Bonnie, U., $\&$ Thomas, F.S. (1995). Stages of embryonic development of the zebrafish. Developmental Dynamics, 203, 253-310.

Monvises, A., Nuangsaeng, B., Sriwattanarothai, N., \& Panijpan, B. (2009). The siamese fighting fish: Well-known generally but little- known scientifically. Journal Science Society of Thailand, 35(2), 816.

Narwati, D.A. (2012). Efektivitas metode transfeksi dalam penyisipan gen red fluorescent protein pada zigot dan embriogenesis ikan cupang alam (Betta imbellis). Skripsi. Program Studi Budidaya Perairan, Fakultas Matematika dan IImu Pengetahuan Alam, Institut Pertanian Bogor. Bogor.
Rahmawati, R. \& Kusrini, E. (2013). Ontogeni dan survival activity index (SAI) larva ikan cupang al am (Betta imbellis, Ladiges 1975) hasil transgenik. Prosiding Forum Inovasi Teknologi Akuakultur.

Tan, H.H. (2011). Diversity of fighting fishes-ikan cupang. Prosiding Forum Inovasi dan Teknologi Akuakultur. Jakarta: Pusat Penelitian dan Pengembangan Perikanan Budidaya, hIm. 37.

Valentin, F.N., Nascimento, N.F., Silva, R.C., Fernandes, J.B.K., Giannecchini, L.G., \& Nakaghi, L.S.O. (2013). Early development of Betta splendens under stereomicroscopy and scanning electron microscopy. Zygote: p. 1-10. Cambridge University Press. Brazil.

Watson, C.A. \& Chapman, F.A. (2002). Artificial incubation of fish eggs. Fact sheet FA-32, Institute of Food and Agricultural Science, University of Florida Extension. Available at http:// edistt.ifas.ufl.edu/fa051.

Yúfera, M. \& Darias, M.J. (2007). The onset of exogenous feeding in marine fish larvae. Aquaculture, 268, 53-63. 